LAND AND LIFE 


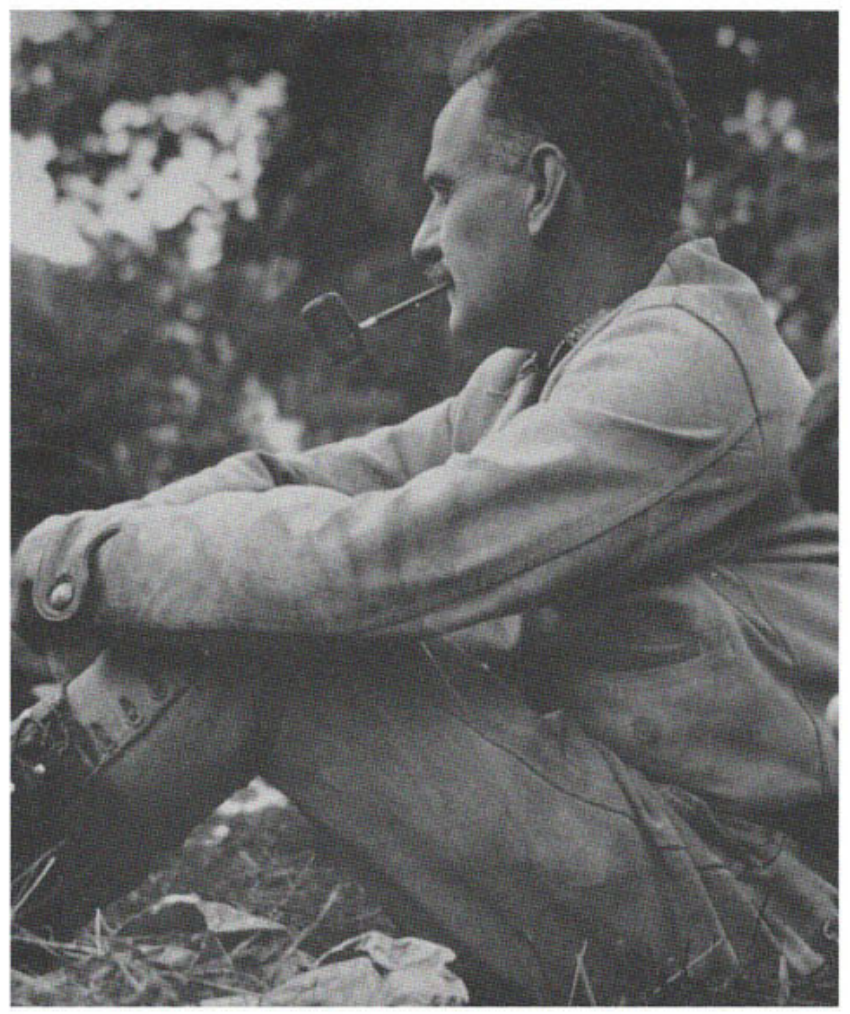

From photograph by K. J. Pelzer, September, 1935.

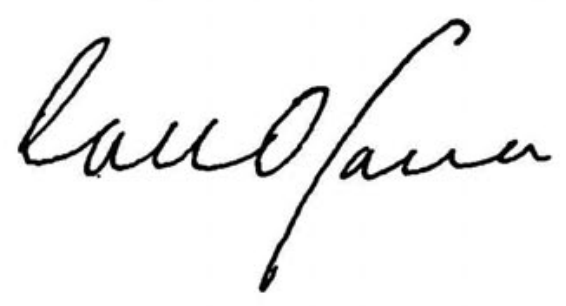

"Locomotion should be slow, the slower the better; and should be often interrupted by leisurely halts to sit on vantage points and stop at question marks." 


\title{
LAND
}

AND

LIFE

\section{A SELECTION FROM THE WRITINGS OF CARL ORTWIN SAUER}

\author{
EDITED BY \\ JOHN LEIGHLY
}

UNIVERSITY OF CALIFORNIA PRESS

BERKELEY AND LOS ANGELES - I 963 


\section{University of California Press}

Berkeley and Los Angeles, California

Cambridge University Press

London, England

(C) 1963 by The Regents of the University of California Library of Congress Catalog Card Number 63-21060 Printed in the United States of America 